\title{
Tujia Chinese
}

National Cancer Institute

\section{Source}

National Cancer Institute. Tujia Chinese. NCI Thesaurus. Code C158165.

A Chinese person from the Tujia ethnic group. 